\title{
PERCEPTION OF LAYPERSONS AND DENTISTS REGARDING ESTHETIC FACIAL CHANGES: A SYSTEMATIC REVIEW
}

\author{
PERCEPÇÃO ESTÉTICA DE LEIGOS E CIRURGIÕES-DENTISTAS EM RELAÇÃO \\ ÀS ALTERAÇÕES FACIAIS: UMA REVISÃO SISTEMÁTICA
}

\section{Priscilla Bispo de Carvalho BARBOSA ${ }^{1}$; Felipe de Souza MATOS ${ }^{1}$; Graziela Oro CERICATO² Henrique Damian ROSÁRIO ${ }^{3}$; Matheus Melo PITHON ${ }^{4}$; Luiz Renato PARANHOS ${ }^{5}$ \\ 1. Postgraduate Program in Dentistry (PRODONTO), Federal University of Sergipe, Aracaju, SE, Brazil; 2. Professor, Dentistry Course, Meridional Faculty - IMED, Passo Fundo, RS, Brazil; 3. Professor, FUNORTE, Florianópolis, SC, Brazil; 4. Professor, Department of Orthodontics, State University of Southwest Bahia, Jéquie, BA, Brazil; 5. Professor, Postgraduate Program in Dentistry (PRODONTO), Federal University of Sergipe, Aracaju, SE, Brazil. paranhos@ ortodontista.com.br}

\begin{abstract}
The need for greater understanding of subjective standards of beauty is important when combining a successful dental plan with the real needs of patients. This study aimed to perform a systematic review to assess whether dentists are more critical in assessing facial esthetics than laypersons. The cross-sectional studies selected compared dentists and laypersons regarding the perception of facial changes through photographs. The survey was conducted in four databases (PubMed, SciELO, LILACS, and OpenGrey) with no restriction of time or language, and was assessed by two reviewers who were based on the PVO strategy. Then, a manual search through the references of the selected articles was performed in order to find surveys that did not fit in said search strategy. The examiners assessed the risk of bias and quality in individual studies. The process of data synthesis was performed through a descriptive analysis of the selected studies. Three relevant articles were selected from an initial total of 979 articles collected. Most studies found that dentists were more critical than laypersons; however, facial modifications were different. Only one survey manipulated the changes on a computer, while the others worked with changes on the patient. Given the methodological diversity of the studies, it was not possible to establish a parameter to validate the results presented.
\end{abstract}

KEYWORDS: Dentists. Esthetics. Face. Perception.

\section{INTRODUCTION}

Facial appearance plays a significant role in the perceptions of society, and influences the level of acceptance of an individual (HAMAMCI et al., 2009; MOTTA et al., 2012; FOO et al., 2013). Facial esthetics are, therefore, a social requirement that directly influences the personal and professional life of a particular person (HAMAMCI et al., 2009; ALMEIDA et al., 2010; BARROS et al., 2012; SOARES et al., 2012; FOO et al., 2013).

Over the years, the study of the face has been increasingly appealing to dental professionals, more specifically in the field of orthodontics (JOHNSTON et al., 2005; TREVISAN; GIL, 2006; NOMURA et al., 2009; ABU ARQOUB; ALKHATEEB, 2011; BARROSO et al., 2012), and face assessments were suggested to verify either the changes caused by growth as orthodontic treatment or facial esthetics alone (HUISINGA-FISCHER et al., 2004; SOH et al., 2005; TREVISAN; GIL, 2006; FABRÉ et al., 2009; TORSELLO et al., 2010; ABU ARQOUB; AL-KHATEEB, 2011; SILVA et al., 2011; EICHENBERGER et al., 2014).

Face assessment by cephalometry was the main method used in orthodontic planning for years because of the easy access to it, the measurement and comparison (overlay) of hard tissue structures, and the belief that following the pattern of cephalometric correction for hard tissues would result in an esthetically pleasing face (SUGUINO et al., 1996). However, it has been observed that the facial pattern guided by cephalometric standards does not always bring a satisfactory result and the satisfaction of the patient (MORIHISA; MALTAGLIATI, 2009).

Limiting the numerical analysis of the face caused an increased concern among orthodontists regarding the role of subjective factors in orthodontic treatment planning (TREVISAN; GIL, 2006; PERON et al., 2012; PARANHOS et al., 2013; SALMÓRIA et al., 2014), which has been enhancing the importance of soft tissues in the analysis of facial esthetics (SPYROPOULOS; HALAZONETIS, 2001; REIS et al., 2006; TREVISAN; GIL, 2006). Thus, many researchers have started to perform this assessment by directly analyzing the face and photographs of patients (SPYROPOULOS; HALAZONETIS, 2001; HUISINGA-FISCHER et al., 2004; SOH et al., 2005; FABRÉ et al., 2009; TORSELLO et al., 2010; ABU ARQOUB; AL-KHATEEB, 2011; SILVA et al., 2011; PERON et al., 2012; EICHENBERGER et al., 2014). This allows for a better assessment of 
Perception of laypersons...

BARBOSA, P. B. C. et al.

facial harmony without exposing the patient to radiation, and at a low cost (PERON et al., 2012).

Motivated by excessive vanity, aiming to achieve the "perfect beauty", and influenced by several media outlets, people who make the contemporary society believe they will only be accepted if they meet the beauty standards imposed. Therefore, health professionals need to become familiar with the expectations of their patients whenever interfering in facial esthetics (ALMEIDA et al., 2010), which requires emphasizing the importance of running a proper medical history investigation so to contemplate and clarify the actual complaints of patients and what encouraged them to seek treatment (MOROSINI et al., 2012).

Given the above, the present review aims to assess through photographs whether dentists are in fact more critical in assessing facial esthetics than laypersons (individuals with no esthetics knowledge).

\section{MATERIAL AND METHODS}

\section{Protocol and Registration}

The present systematic review was conducted following the instructions of the Preferred Reporting Items for Systematic Reviews and Meta-Analyses (PRISMA) (MOHER et al., 2009) (www.prisma-statement.org).The systematic review protocol was registered at the International Prospective Register of Systematic Reviews (PROSPERO), under protocol CRD42015023707.

\section{Eligibility Criteria}

Focused Question. The present research aimed to answer the following focused question: Are dentists more critical in assessing facial esthetics when compared to laypersons?

The research question was based on the PVO strategy for Systematic Exploratory Review, where $\mathbf{P}$ stands for population, context, and/or problem-situation, $\mathbf{V}$ stands for variables, and $\mathbf{O}$ stands for desirable or undesirable outcomes.

Inclusion criteria. Articles comparing the perception of facial esthetics among dentists and laypersons using digital photographs with no restrictions of year, publication status or language.

Exclusion criteria. Articles investigating facial esthetics through silhouettes (black and white images that do not consider extrinsic factors of the face and are extremely relevant in the assessment of facial attractiveness); studies showing no facial changes as the object of assessment research; studies of patients with cleft lip and palate, or syndromics; articles investigating facial esthetics with no measuring scale; and articles investigating facial esthetics with no dentists among the examiners.

\section{Information Sources}

A systematic search was performed in PubMed, SciELO, LILACS, and OpenGrey databases. The OpenGrey database was particularly used to search the grey literature, avoiding potential selection bias.

\section{Search}

Medical Subject Headings (MeSH) were used to select the controlled keywords: "Face", "Esthetics", "Perception", and "Dentists". In addition, the following uncontrolled keywords were used: "Symmetry", "Asymmetry", "Laypersons", and "Laymen". Boolean operators were used (OR and AND) for the combination of keywords. This survey was conducted in May 15, 2015, as shown in Table 1.

The results obtained were exported to the software Mendeley Desktop 1.13.3 (Mendeley ${ }^{\mathrm{TM}}$ Ltd, London, UK), where duplicity was verified.

Table 1. Electronic databases and research strategy.

\begin{tabular}{|c|c|c|}
\hline Database & Search Strategy & Total \\
\hline \multirow{5}{*}{$\begin{array}{l}\text { PubMed } \\
\text { http://www.ncbi.nlm.nih.g } \\
\text { ov/pubmed/ }\end{array}$} & $\begin{array}{l}\text { ("face" [MeSH Terms] OR "face" [All Fields]) AND ("esthetics" } \\
\text { [MeSH Terms] OR "esthetics" [All Fields]) AND ("perception" } \\
\text { [MeSH Terms] OR "perception" [All Fields]) }\end{array}$ & 480 \\
\hline & ("dentists" [MeSH Terms] OR "dentists" [All Fields]) AND & \\
\hline & $\begin{array}{l}\text { laypersons [All Fields] AND ("perception" [MeSH Terms] OR } \\
\text { "perception" [All Fields]) }\end{array}$ & 27 \\
\hline & $\begin{array}{l}\text { ("dentists" [MeSH Terms] OR "dentists" [All Fields]) AND } \\
\text { laymen [All Fields] AND ("perception" }[\mathrm{MeSH} \text { Terms] OR } \\
\text { "perception" [All Fields]) }\end{array}$ & 2 \\
\hline & $\begin{array}{l}\text { ("face" [MeSH Terms] OR "face" [All Fields]) AND ("Symmetry } \\
\text { [Basel]" [Journal] OR "symmetry" [All Fields]) AND } \\
\text { ("perception" [MeSH Terms] OR "perception" [All Fields]) }\end{array}$ & 124 \\
\hline
\end{tabular}


BARBOSA, P. B. C. et al.

\begin{tabular}{|c|c|c|}
\hline & $\begin{array}{l}\text { ("face" [MeSH Terms] OR "face" [All Fields]) AND asymmetry } \\
\text { [All Fields] AND ("perception" [MeSH Terms] OR "perception" } \\
\text { [All Fields]) }\end{array}$ & 305 \\
\hline \multirow{4}{*}{$\begin{array}{l}\text { SciELO } \\
\text { http://www.scielo.org/ }\end{array}$} & Face AND Estética AND Percepção (Portuguese) & 1 \\
\hline & Dentistas AND Leigos AND Percepção (Portuguese) & 3 \\
\hline & Face AND Simetria AND Percepção (Portuguese) & 2 \\
\hline & Face AND Assimetria AND Percepção (Portuguese) & 2 \\
\hline \multirow{5}{*}{$\begin{array}{l}\text { LILACS } \\
\text { lilacs.bvsalud.org/ }\end{array}$} & $\begin{array}{l}\text { face AND esthetics AND perception AND (instance:"regional") } \\
\text { AND ( db:["LILACS"]) }\end{array}$ & 15 \\
\hline & $\begin{array}{l}\text { tw: (dentists AND laypersons AND perception) AND (instance: } \\
\text { "regional") AND (db: ["LILACS"]) }\end{array}$ & 1 \\
\hline & $\begin{array}{l}\text { tw: (dentists AND laymen AND perception) AND (instance: } \\
\text { "regional") AND (db: ["LILACS"]) }\end{array}$ & 2 \\
\hline & $\begin{array}{l}\text { tw: (face AND symmetry AND perception) AND (instance: } \\
\text { "regional") AND (db: ["LILACS"]) }\end{array}$ & 4 \\
\hline & $\begin{array}{l}\text { tw: (face AND asymmetry AND perception) AND (instance: } \\
\text { "regional") AND (db: ["LILACS"]) }\end{array}$ & 4 \\
\hline \multirow{6}{*}{$\begin{array}{l}\text { OpenGrey } \\
\text { http://www.opengrey.eu/ }\end{array}$} & "face" AND “esthetics" AND “perception" & 0 \\
\hline & “dentists" AND "laypersons" AND “perception" & 0 \\
\hline & "dentists" AND "laymen" AND “perception" & 0 \\
\hline & "face" AND "symmetry" AND "perception" & 2 \\
\hline & "face" AND "asymmetry" AND "perception" & 5 \\
\hline & $\begin{array}{c}\text { Total } \\
\end{array}$ & 979 \\
\hline
\end{tabular}

\section{Study Selection}

Selection was performed at different times. Titles and abstracts were systematically assessed for eligibility by two reviewers, who were not blind to authors or journals. Whenever the title and abstract of articles did not present enough information, full texts were obtained and analyzed to decide on their eligibility. Articles presenting a title that fit the theme but with no available abstracts, were also obtained and fully analyzed.

The full texts of previously eligible articles were downloaded and read so to verify the presence of every inclusion criteria. In specific cases, the authors of potentially eligible articles were contacted by e-mail and asked for missing information. The rejected articles were registered separately, displaying the reasons for exclusion. The references of the selected studies were analyzed for potential studies that were not identified in the search strategy used.

\section{Data collection process}

Two examiners assessed the risk of bias and quality in individual studies. In case of disagreement, a third examiner was consulted. At this point, the review was blindly performed, masking the names of authors and journals, and avoiding any potential bias and conflicts of interest during sample selection.

\section{Data items}

After triage, the full text of the pre-selected articles was re-examined and data were extracted in a standardized manner. The information extracted and recorded from the articles were authors, publication year, place of study, objective, sample characteristics, age of evaluators, photographic method, measurement scale used, and main outcomes.

\section{Risk of bias/quality in individual studies}

The selected studies assessed the risk of bias and quality in individual studies using the checklist adapted from Cericato et al. (2015). Each study received a score of low quality ( $0-8$ points), medium quality (9-11 points), and high quality (12-14 points).

\section{Summary measures}

The process of data synthesis was performed through a descriptive analysis of the selected studies, and the final product of the analysis was presented in narration/dissertation form.

\section{Planned methods of analysis}

A meta-analysis was planned, provided that data from the included studies were relatively homogeneous. The risk of bias is only to be applied if meta-analysis was possible. 


\section{RESULTS}

\section{Study Selection}

A flowchart describing the process of identification, inclusion, and exclusion of studies is shown in Figure 1. A total of 979 results was retrieved during the first selection phase; after removing duplicates, the total was 874 results. Next, 882 studies were excluded for different reasons (see
Results excluded by reason, in Figure 1). Thirty-two full articles were assessed for eligibility, and three additional articles were included after a manual search in the references lists. After applying inclusion and exclusion criteria, six articles remained eligible. Then, three articles were excluded by low methodological quality, and three articles remained eligible (Figure 1).

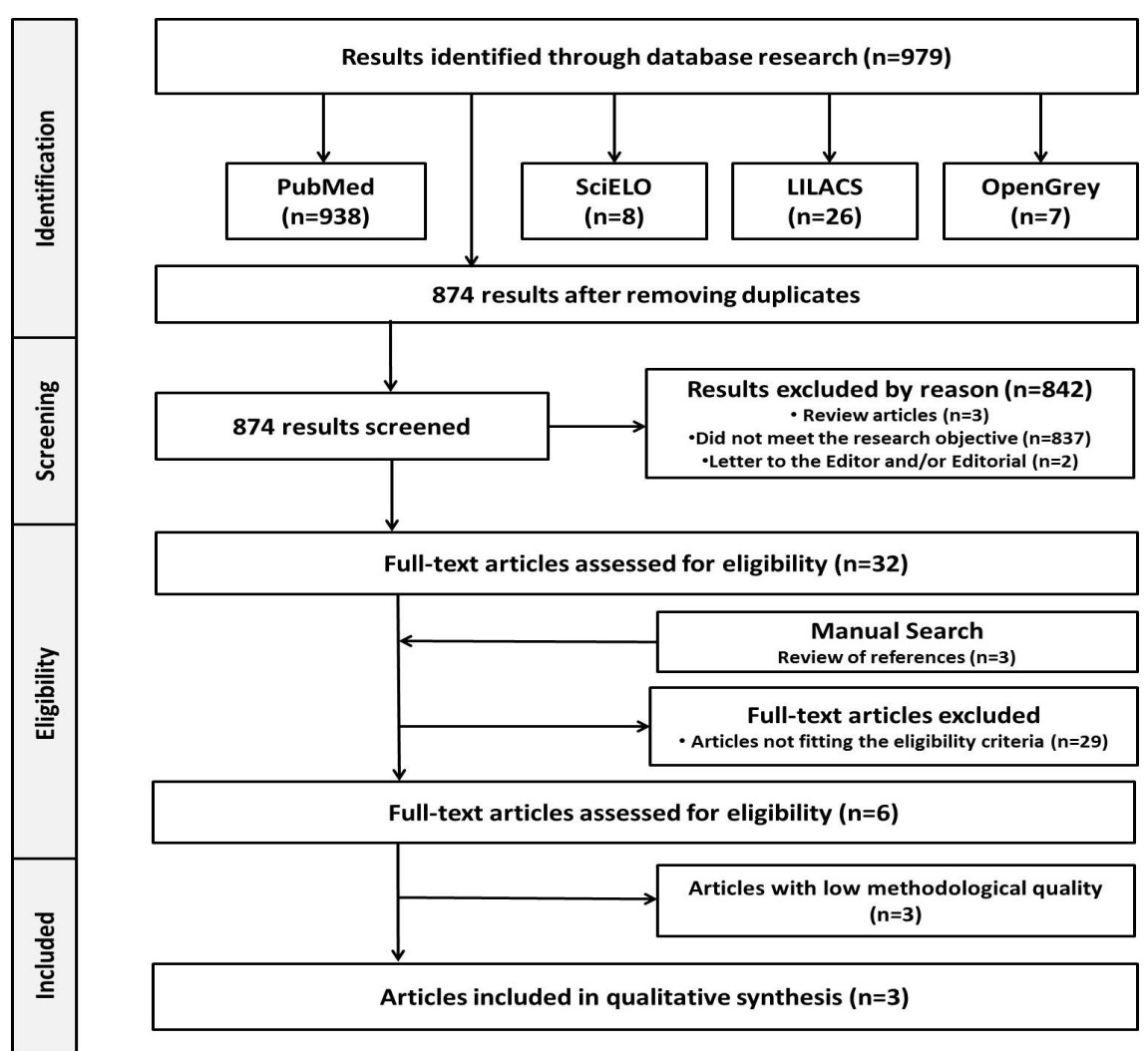

Figure 1. Flowchart of literature search and selection criteria.

The results of this search showed that the concern with facial esthetics has drawn increasing attention from the dental profession. This statement is supported by the growing number of research on this subject over the years, as observed in Figure 2.

\section{Risk of bias/quality among results in individual studies}

From the three eligible studies, it was particularly observed that no studies presented sample calculations, only one study properly presented the inclusion and exclusion criteria for the research (TORSELLO et al., 2010), none of the researches reported ethical concerns, and the three articles discussed study limitations (MAPLE et al., 2005; FABRÉ et al., 2009; SILVA et al., 2011) (Table 2).

The studies were heterogeneous, and none of them met all the methodological criteria for quality. The three studies presented moderate methodological quality. Table 2 shows scores and criteria used. 
BARBOSA, P. B. C. et al.

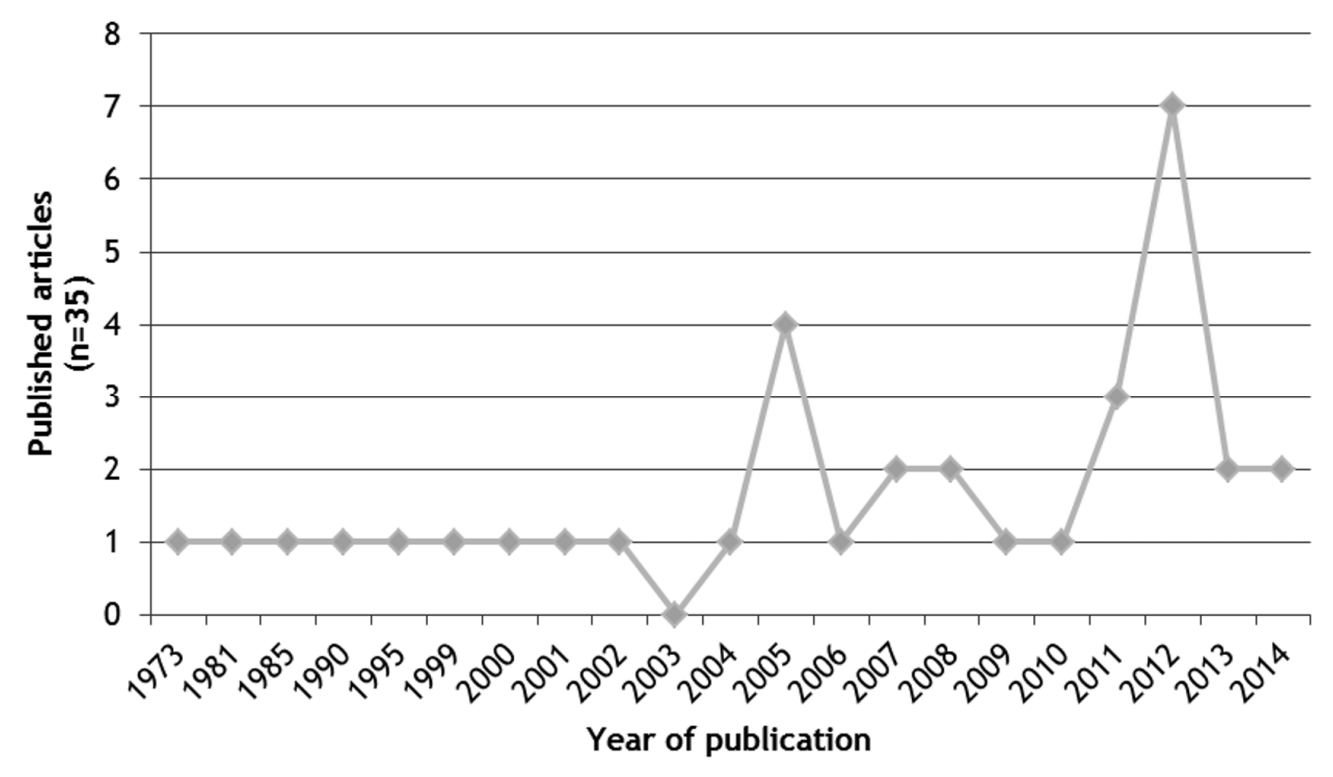

Figure 2. Distribution of articles with the same research topic according to the year of publication.

\section{Syntheses of results}

According to the proposed theme and the criteria set forth herein, two types of facial changes were presented in the studies included in the final sample: changes in the anteroposterior direction (FABRÉ et al., 2009; TORSELLO et al., 2010) or the lateral-lateral direction (SILVA et al., 2011) (Table 3).

Within the methodology applied, only one study (SILVA et al., 2011) differed on the use of measurement scales. While Torsello et al. (2010) and Fabré et al. (2009) used the Visual Analogue Scale (VAS) to measure the degree of attractiveness of the images used in their research, Silva et al. (2011) used a point scale from 0 (not attractive) to 10 (extremely attractive) for the same purpose.

Although Torsello et al. (2010) and Fabré et al. (2009) address the same subject and use the same measurement scale, there were conflicting results regarding the perceptions of laypersons and dentists.

In only one study (TORSELLO et al., 2010) assessing attractiveness, facial changes were simulated in computer programs. Two other studies (FABRÉ et al., 2009; SILVA et al., 2011) used photos with real changes performed on models, where patients moved the jaw by themselves.

\section{Risk of bias across studies}

The studies selected for this analysis were considered heterogeneous and did not present compatible data to allow a meta-analysis. 
Table 2. Analysis of the potential risk of bias and individual quality of the eligible articles.

\begin{tabular}{|c|c|c|c|c|c|c|c|c|c|c|c|c|c|}
\hline Author & $\begin{array}{c}\text { Q.1 } \\
(1 \text { point })\end{array}$ & $\begin{array}{c}\text { Q.2 } \\
\text { (1 Point) } \\
\end{array}$ & $\begin{array}{c}\text { Q.3 } \\
(1 \text { point }) \\
\end{array}$ & $\begin{array}{c}\text { Q.4 } \\
(1 \text { point })\end{array}$ & $\begin{array}{c}\text { Q.5 } \\
\text { (2 Points) } \\
\end{array}$ & $\begin{array}{c}\text { Q.6 } \\
\text { (2 Points) } \\
\end{array}$ & $\begin{array}{c}\text { Q.7 } \\
\text { (2 points) }\end{array}$ & $\begin{array}{c}\text { Q.8 } \\
\text { (1 Point) }\end{array}$ & $\begin{array}{c}\text { Q.9 } \\
\text { (1 point) }\end{array}$ & $\begin{array}{c}\text { Q.10 } \\
(1 \text { point })\end{array}$ & $\begin{array}{c}\text { Q.11 } \\
\text { (1 point) }\end{array}$ & Total & $\begin{array}{l}\text { Overall } \\
\text { quality }\end{array}$ \\
\hline Spyropoulos and Halazonetis, 2001 & $\sqrt{ }$ & $\sqrt{ }$ & -- & $\sqrt{ }$ & -- & -- & -- & -- & $\sqrt{ }$ & $\sqrt{ }$ & -- & 5 Points & + \\
\hline Maple et al., 2005 & $\sqrt{ }$ & $\sqrt{ }$ & -- & $\sqrt{ }$ & -- & -- & $\sqrt{ }$ & $\sqrt{ }$ & -- & $\sqrt{ }$ & $\sqrt{ }$ & 8 Points & + \\
\hline $\begin{array}{l}\text { Fabré et al., } \\
2009\end{array}$ & $\sqrt{ }$ & $\sqrt{ }$ & -- & $\sqrt{ }$ & -- & $\sqrt{ }$ & $\sqrt{ }$ & $\sqrt{ }$ & $\sqrt{ }$ & $\sqrt{ }$ & $\sqrt{ }$ & 11 Points & ++ \\
\hline Torsello et al. 2010 & $\sqrt{ }$ & $\sqrt{ }$ & -- & $\sqrt{ }$ & -- & $\begin{array}{c}\sqrt{ } \\
\text { (1 Point) }\end{array}$ & $\sqrt{ }$ & $\sqrt{ }$ & $\sqrt{ }$ & $\sqrt{ }$ & -- & 9 Points & ++ \\
\hline $\begin{array}{l}\text { Silva et al., } \\
2011\end{array}$ & $\sqrt{ }$ & $\sqrt{ }$ & -- & $\sqrt{ }$ & -- & $\begin{array}{c}\sqrt{ } \\
\text { (1 point) }\end{array}$ & $\sqrt{ }$ & $\sqrt{ }$ & $\sqrt{ }$ & $\sqrt{ }$ & $\sqrt{ }$ & 10 Points & ++ \\
\hline Barroso et al., 2012 & $\sqrt{ }$ & $\sqrt{ }$ & -- & $\sqrt{ }$ & -- & -- & $\sqrt{ }$ & $\sqrt{ }$ & $\sqrt{ }$ & v & -- & 8 Points & + \\
\hline
\end{tabular}

Q.1- The abstract clearly presents the study objective, methodology, results and conclusion. Q.2- The study exposes the objective clear and precisely. Q.3- The ethical aspects of the research are cited in the text. Q.4- The research design is described. Q.5- The sample size calculation is reported. Q.6- The eligibility (1 point) and exclusion (1 point) criteria are described. Q.7- The research design is adequate (randomization and blinding). Q.8- The statistical tests are described. Q.9- The $p$ values are

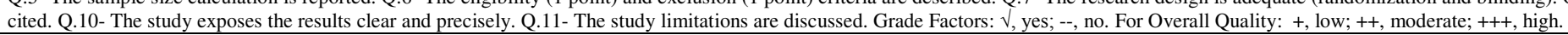

Table 3. Summary of study descriptive characteristics of included studies.

\begin{tabular}{|c|c|c|c|c|c|c|}
\hline $\begin{array}{l}\text { Author and } \\
\text { year }\end{array}$ & Aims & Sample profile & $\begin{array}{l}\text { Examiner } \\
\text { age }\end{array}$ & $\begin{array}{c}\text { Photographic } \\
\text { modality }\end{array}$ & Measuring scale & Outcome \\
\hline $\begin{array}{c}\text { Fabré et al. } \\
2009 \\
\text { Switzerland* }\end{array}$ & $\begin{array}{l}\text { To evaluate the facial profile of orthodontic patients with } \\
\text { Angle's malocclusion Class III prior to surgical procedures }\end{array}$ & $\begin{array}{c}18 \text { Orthodontists } \\
\left(90^{\lambda} ; 9+\right) \\
18 \text { Laypersons } \\
\left(4 \delta^{\lambda} ; 14+\right)\end{array}$ & $\begin{array}{c}\text { Not } \\
\text { mentioned }\end{array}$ & $\begin{array}{l}\text { Lateral profile } \\
\text { photographs }\end{array}$ & $\begin{array}{l}\text { VAS (non-attractive- } \\
\text { very attractive) }\end{array}$ & $\begin{array}{l}\text { Dentists are more critical } \\
\text { with facial aesthetics }\end{array}$ \\
\hline $\begin{array}{l}\text { Torsello et al. } \\
2010 \\
\text { Italy* }\end{array}$ & $\begin{array}{l}\text { To evaluate labial protrusion and retrusion associated with } \\
\text { protrusion of nose and chin. }\end{array}$ & $\begin{array}{l}15 \text { Orthodontists } \\
\text { (gender not reported) } \\
15 \text { Laypersons } \\
\text { (gender not reported) }\end{array}$ & $\begin{array}{l}\text { Not } \\
\text { mentioned }\end{array}$ & $\begin{array}{l}\text { Lateral profile } \\
\text { photographs }\end{array}$ & $\begin{array}{l}\text { VAS (non-attractive- } \\
\text { very attractive) }\end{array}$ & $\begin{array}{l}\text { Laypersons are more critical } \\
\text { with facial aesthetics }\end{array}$ \\
\hline $\begin{array}{c}\text { Silva et al. } \\
2011 \\
\text { Brazil* }\end{array}$ & To evaluate lateral deviations of the mandible & $\begin{array}{c}30 \text { Orthodontists } \\
\left(11 \jmath^{\lambda} ; 19 \mathrm{c}+\right) \\
30 \text { Laypersons } \\
(13 \hat{\jmath} ; 17+9)\end{array}$ & $\begin{array}{l}\text { Not } \\
\text { mentioned }\end{array}$ & $\begin{array}{l}\text { Frontal } \\
\text { photographs }\end{array}$ & $\begin{array}{l}\text { Scores from } 0 \text { to } 10(6 \\
\quad=\text { acceptable })\end{array}$ & $\begin{array}{l}\text { Dentists are more critical } \\
\text { with facial aesthetics }\end{array}$ \\
\hline
\end{tabular}




\section{DISCUSSION}

The discussion of facial esthetic standards is increasingly common in society and consequently in dentistry. Patients are more critical about facial esthetics and this reflects a concern among dental professionals to meet the requirements of those individuals.

Although the terms "orthodontist" and "orthodontics" were not used in the combination of keywords of the present study, so to provide a higher range of results in the collection of studies related to the subject, all of the researches hereby included used orthodontists in their study comparisons of the perception of facial esthetics, as shown in Table 1. This translates the fact that the field of orthodontics is closely related to facial cosmetic dentistry, also reflecting the concern with the subjective opinion of orthodontists regarding this matter.

For greater uniformity of results, we only included items that used photos for the assessment of facial attractiveness. Although they were visual assessments of esthetic perceptions of the face through silhouettes with no extrinsic factors (skin color, makeup, hair, etc.) that could hinder the assessment, we believe that the use of photographs more faithfully translates our reality, since several facial changes may present different results when influenced by certain extrinsic factors.

In this review, we verified that, even with the range of studies that permeate the field of perception of facial attractiveness involving dentists and laypersons, the results are inconsistent due to the lack of standardization of the type of change performed and the methodology applied. Regarding the studies addressing sagittal changes (anteroposterior), Fabré et al. (2009) and Torsello et al. (2010) presented studies and results that add up. While the first authors only assessed the perception of changes on protrusion through the analysis of patients with different levels of Class III, the latter assessed the perception of lip protrusion and retrusion associated with changes in nose and chin. The results of these studies indicated that both laypersons and orthodontists noted the changes made, and classified them as unpleasant compared to the normal standard (Class I patients).

However, even though these studies use a similar number of evaluators per group and the same rating scale (VAS), the results were divergent regarding the critical power of groups of evaluators involved in the research. For Fabré et al. (2009), orthodontists were more critical in their assessments than laypersons, and gave lower scores when evaluating the images. This result agrees with the studies of Abu-Arqoub \& Al-Khateeb (2010), Barroso et al. (2012), and Falkensammer et al. (2014), who also conducted research on the perception of facial changes. As for Torsello et al. (2010), laypersons proved to be more critical, giving the lowest scores. The results shown by the latter study do not present a clear explanation, considering that orthodontists generally tend to be more sensitive in perceiving facial changes when compared to laypersons, because of their professional knowledge and by daily handling these types of changes.

Although Silva et al. (2011) and Fabré et al. (2009) have addressed different facial changes in their studies, both showed similar results when reporting a higher sensitivity from orthodontists in detecting these changes. The first authors addressed the assessment of these deformations in a front view through the lateral displacement of the jaw, but using a numerical interval assessment scale. The latter, although researching the perception of sagittal changes using the VAS (Visual Analogue Scale) as measurement scale, showed the same result as the previous authors. This shows that the use of a different scale in the assessment does not represent a significant influence on the evaluation process.

Considering the analysis of the three selected studies, which assessed variables such as type of change, rating scale, and auditing team, the way changes were made seemed to represent a relevant factor. Fabré et al. (2009) and Silva et al. (2011) used real changes in their assessments, while Torsello et al. (2010) used changes made by computer programs, which may be a limiting factor for the reliable reproducibility of the change to be analyzed.

Further studies with more standardized methods are suggested in order to definitely clarify who is more critical in the subjective assessment of facial characteristics, so that results may provide some guidance for the clinical practice and increase the strength of evidences.

\section{CONCLUSION}

By conducting this systematic review and based on the eligible studies, it could not be concluded whether dentists are indeed more critical in the photographic assessment of facial esthetics than laypersons (individuals with no esthetics knowledge). 
RESUMO: A necessidade de uma maior compreensão dos padrões subjetivos da beleza é importante quando se combina um plano odontológico de sucesso com as necessidades reais dos pacientes. Este estudo teve como objetivo realizar uma revisão sistemática para avaliar se dentistas são mais exigentes na avaliação da estética facial do que os leigos. Os estudos transversais selecionados compararam dentistas e leigos em relação à percepção de alterações faciais através de fotografias. A pesquisa foi realizada em quatro bases de dados (PubMed, SciELO, LILACS e OpenGrey), sem restrição de tempo ou de idioma, e foi realizada por dois revisores que utilizaram como referência a estratégia PVO. Em seguida, foi realizada uma busca manual através das referências dos artigos selecionados, a fim de encontrar pesquisas que não se encaixavam na referida estratégia de busca. Os examinadores avaliaram o risco de viés e qualidade nos estudos individuais. O processo de síntese dos dados foi realizado através de uma análise descritiva dos estudos selecionados. Três artigos relevantes foram selecionados de um total inicial de 979 artigos coletados. A maioria dos estudos revelou que os dentistas eram mais críticos do que os leigos; no entanto, as modificações faciais eram diferentes. Apenas uma pesquisa manipulou as alterações em um computador, enquanto as outras trabalharam com mudanças no paciente. Diante da diversidade metodológica dos estudos, não foi possível estabelecer um parâmetro para validação dos resultados apresentados.

PALAVRAS-CHAVE: Cirurgião-dentista. Estética. Face. Percepção.

\section{REFERENCES}

ABU ARQOUB, S. H.; AL-KHATEEB, S. N. Perception of facial profile attractiveness of different anteroposterior and vertical proportions. Eur J Orthod. v. 33, p. 103-111, 2011. 10.1093/ejo/cjq028.

ALMEIDA, M. D.; FARIAS, A. C. R.; BITTENCOURT, M. A. V. Influence of mandibular sagittal position on facial esthetics. Dental Press J Orthod, v. 15, p. 87-96, 2010. 10.1590/S2176-94512010000200012.

BARROS E. C. S.; CARVALHO, M. D. O.; MELLO, K. C. F. R.; BOTELHO, P.; NORMANDO, D. The ability of orthodontists and laypeople in the perception of gradual reduction of dento gingival exposure while smiling. Dental Press J Orthod. v. 17, p. 81-86, 2012. 10.1590/S2176-94512012000500012.

BARROSO, M. C. F.; SILVA, N. C. F.; QUINTÃO, C. C. A. The ability of orthodontists and laypeople to discriminate mandibular stepwise advancements in a Class II retrognathic mandible. Prog Orthod. v. 13, p. 141-147, 2012. 10.1016/j.pio.2011.12.001.

CERICATO, G. O.; BITTENCOURT, M. A. V.; PARANHOS, L. R. Validity of the assessment method of skeletal maturation by cervical vertebrae: a systematic review and meta-analysis. Dento Maxillo Fac Radiol. v. 44, 20140270, 2015. 10.1259/dmfr.20140270.

EICHENBERGER, M.; STAUDT, C. B.; PANDIS, N.; GNOINSKI, W.; ELIADES, T. Facial attractiveness of patients with unilateral cleft lip and palate and of controls assessed by laypersons and professionals. Eur $\mathbf{J}$ Orthod. v. 36, p. 284-289, 2014. 10.1093/ejo/cjt047.

FABRÉ, M.; MOSSAZ, C.; CHRISTOU, P.; KILIARIDIS, S. Orthodontists' and laypersons' aesthetic assessment of Class III subjects referred for orthognathic surgery. Eur J Orthod. v. 31, p. 443-448, 2009. 10.1093/ejo/cjp002.

FALKENSAMMER F.; LOESCH A.; KRALL C.; WEILAND F.; FREUDENTHALER J. The Impact of Education on the Perception of Facial Profile Aesthetics and Treatment Need. Aesthetic Plast Surg. v. 38, p. 620-631, 2014. 10.1007/s00266-014-0329-z.

FOO, P.; SAMPSON, W.; ROBERTS, R; JAMIESON, L.; DAVID, D. Facial aesthetics and perceived need for further treatment among adults with repaired cleft as assessed by cleft team professionals and laypersons. Eur $\mathbf{J}$ Orthod. v. 35, p. 341-346, 2013. 10.1093 / ejo / cjr129. 
Perception of laypersons...

BARBOSA, P. B. C. et al.

HAMAMCI, N.; BAŞARAN, G.; UYSAL, E. Dental Aesthetic Index scores and perception of personal dental appearance among Turkish university students. Eur J Orthod. v. 31, p. 168-173, 2009. 10.1093/ejo/cjn083.

HUISINGA-FISCHER, C. E.; SOUREN, J. P. H. J. A.; WERKEN, F. S. B.; PRAHL-ANDERSEN, B.; VAN GINKEL, F. M. A. Perception of symmetry in the face. J Craniofac Surg. v. 15, p. 128-134, 2004. 10.1016/j.ajodo.2004.02.018.

JOHNSTON, C.; HUNT, O.; BURDEN, D.; STEVENSON, M.; HEPPER, P. The influence of mandibular prominence on facial attractiveness. Eur J Orthod. v. 27, p. 129-133, 2005. 10.1590/S217694512010000200012 .

MAPLE, J. R.; VIG, K. W. L.; BECK, F. M.; LARSEN, P. E.; SHANKER, S. A comparison of providers' and consumers' perceptions of facial-profile attractiveness. Am J Orthod Dentofacial Orthop. v. 128, p. 690-696, 2005. 10.1016/j.ajodo.2004.09.030.

MOHER, D.; LIBERATI, A.; TETZLAFF, J.; ALTMAN, D. G. Preferred reporting items for systematic reviews and meta-analyses: the PRISMA statement. Ann Intern Med. v. 151, p. 264-269, 2009. 10.1371/journal.pmed.1000097.

MORIHISA, O.; MALTAGLIATI, L. A. Comparative evaluation among facial attractiveness and subjective analysis of Facial Pattern. Rev Dent Press J Ortodon Ortop Facial. v. 14, p. 46.e1-46.e9, 2009. 10.1590/S1415-54192009000600006.

MOROSINI, I. A. C.; PERON, A. P. L. M.; CORREIA, K. R.; MORESCA, R. Study of face pleasantness using facial analysis in standardized frontal photographs. Dental Press J Orthod. v. 17, p. 24-34, 2012. 10.1590/S2176-94512012000500005.

MOTTA, A. F. J; MUCHA, J. N.; SOUZA, M. M. G. Influence of certain tooth characteristics on the esthetic evaluation of a smile. Dental Press J Orthod. v. 17, n. 25, p. e1-7, 2012. 10.1590/S217694512012000300008.

NOMURA M.; MOTEGI, E.; HATCH, J. P.; GAKUNGA, P. T.; NG’ANG'A, P. M.; RUGH, J. D. YAMAGUCHI, H. Esthetic preferences of European American, Hispanic American, Japanese, and African judges for soft-tissue profiles. Am J Orthod Dentofacial Orthop. v. 135, p. S87-S95, 2009. 10.1016/j.ajodo.2008.02.019.

PARANHOS, L. R.; BENEDICTO, E. M.; RAMOS, A. L. Changes of the upper lip in orthodontic and orthopedic treatment of angle's class II malocclusion. Indian J Dent Res. v. 24, p. 351-355, 2013. 10.4103/0970-9290.118002.

PERON, A. P. L. M.; MOROSINI, I. C.; CORREIA, K. R.; MORESCA, R.; PETRELLI, E. Photometric study of divine proportion and its correlation with facial attractiveness. Dental Press J Orthod. v. 17, p. 124-131, 2012. 10.1590/S2176-94512012000200022.

REIS, S. A. B.; ABRÃO, J.; CAPELOZZA FILHO, L.; CLARO, C. A. A. Numeric facial analysis of the profile in Pattern I Brazilians. Rev Dent Press Ortodon Ortop Facial. v. 11, p. 24-34, 2006. 10.1590/S141554192006000600005.

SALMÓRIA, I.; FURTADO, A.; ROSÁRIO, H. D.; FURTADO, G. C.; PARANHOS, L. R. Arnett and bergman facial analysis compared with aesthetic perception by lay people and dentists (general practitioners and orthodontists). Biosci J. v. 30, p. 297-303, 2014.

SILVA, N. C. F.; AQUINO, E. R. B.; MELLO, K. C. F. R.; MATTOS, J. N. R.; NORMANDO, D. Orthodontists' and laypersons' perception of mandibular asymmetries. Dental Press J Orthod. v. 16, p. 38.e18, 2011. 10.1590/S2176-94512011000400007. 
Perception of laypersons...

BARBOSA, P. B. C. et al.

SOARES, D. M.; PALMEIRA, P. T. S. S.; PEREIRA, V. F.; SANTOS, M. E. S. M.; TASSITANO, R. M.; LAUREANO FILHO, J. R. Evaluation of the main criteria of facial profile aesthetics and attractiveness. Rev Bra Circ Plást. v. 27, p. 547-551, 2012. 10.1590/S1983-51752012000400013.

SOH, J.; CHEW, M. T.; WONG, H. B. A comparative assessment of the perception of Chinese facial profile esthetics. Am J Orthod Dentofacial Orthop. v. 127, p. 692-699, 2005. 10.1016/j.ajodo.2004.02.018.

SPYROPOULOS, M. N.; HALAZONETIS, D. J. Significance of the soft tissue profile on facial esthetics. Am J Orthod Dentofacial Orthop. v. 119, p. 464-471, 2001. 10.1067/mod.2001.113656.

SUGUINO, R.; RAMOS, A. L.; TERADA, H. H.; FURQUIM, L. Z.; MAEDA, L.; SILVA FILHO, O. G. Facial Analysis. Rev Dent Press Ortodon Ortop Facial. v. 1, p. 86-107, 1996.

TORSELLO, F.; GRACI, M.; GRANDE, N. M.; DELI, R. Relationships between facial features in the perception of profile attractiveness. Prog Orthod. v. 11, p. 92-97, 2010. 10.1016/j.pio.2010.04.002.

TREVISAN, F.; GIL, C. T. L. A. Photogrametric and subjective analysis of the facial profile in young subjects with normal occlusion. Rev Dent Press Ortodon Ortop Facial. v. 11, p. 24-35, 2006. 10.1590/S141554192006000400004. 